\title{
The Use of Mobile Phones and their Apps in Tourism Marketing in the Kingdom of Saudi Arabia
}

\author{
https://doi.org/10.3991/ijim.v15i06.20635 \\ Nabil Mohemmed Al-Hazmi \\ Prince Sattam bin Abdulaziz University, Al-Kharj, Kingdom of Saudi Arabia \\ Taiz University, Taiz, Yemen \\ hazminabil181220@yandex.com
}

\begin{abstract}
This study aims at identifying the importance of using smartphone apps in tourism marketing in Al-Kharj Governorate in the Kingdom of Saudi Arabia. The study used the descriptive and analytical approach in studying its hypotheses and achieving its objectives. It concluded that the majority of the study sample use smartphones and their tourism apps in the process of obtaining information and complete the purchasing process for the tourist trip. These apps are used to attract tourists as the best advertising method that attracts the targeted market. The study presented a set of recommendations, the most important of which is increasing cooperation between the authorities that supervise the tourism activity in the governorate when designing these apps and working to develop the technological infrastructure in line with the nature of development in the field of smartphones.
\end{abstract}

Keywords-Mobile phone, tourism, marketing, smartphone apps

\section{$1 \quad$ Introduction}

Mobile marketing is that marketing which relies on smartphones as a means of communication and marketing. This type of marketing aims at delivering information to promote for a product, idea or service to customers by sending them to their mobile phones. Mobile marketing is a multi-channel internet marketing method. Which focuses on reaching a specific audience on their smartphones, board devices, or any other related devices through the web sites: Email, SMS and MMS, Social media or mobile applications. Mobile marketing can provide customers with sensitive, personalized time and location information that encourages goods, services and ideas in a more theoretical way. Mobile marketing is defined as "any marketing activity that takes place through a network in some place to which consumers are constantly connected by using a personal mobile device. Most of the organizations - especially those working in the field of tourism and hotels - have realized the importance and necessity of relying on mobile devices in general as a means and smartphones technologies and their various apps in particular in promoting and marketing their various products and services, aiming at ensuring its continued presence in a changing market and then the success and continuation of the tourism and hotel work. The 
method by which tourism services are selected and booked, a purchase decision is made, and customers are contacted. From here, travel and tourism organizations in the Kingdom of Saudi Arabia began to use smartphones and their apps in their practices for their work because smartphones technology and its various apps provide many opportunities for these organizations to increase its competitiveness, whether at the local or international level, and to start using these apps by the tourists themselves as well. There are many benefits for tourists who do searches, and buy trips and tourism services through smart phone apps through the ease of searching, planning and purchasing all tourism services at any time and place, and saving the time needed to obtain tourism services; such as: online payment applications, the possibility of obtaining the lowest prices and the best offers, and obtaining extensive information on everything related to the tourist trip.

\subsection{Study problem}

The study problem lies on the many barriers that the tourist destinations face in using modern technology in marketing their tourism products, catch up with this technological revolution, and take advantage of it in its business fields to face regional and global competition. Through the spread of the Internet, we notice a change, and with the growth of modern technology, and in the behavior of tourists, as they have become more aware and connected than ever before with this technology. The study problem can be formulated through the following questions:

1. To what extent have smartphones and their apps been used in tourism marketing in the Kingdom of Saudi Arabia?

2. Does the use of smartphones and their apps effect on marketing tourism products and services in the Kingdom of Saudi Arabia?

\subsection{Study objectives}

The study objectives are as follows:

1. Clarifying the importance of using smartphones and their apps in tourism marketing.

2. Identifying the extent of the use of smartphones by customers and the extent of their satisfaction with the related services to the tourism activity, which they provide.

\subsection{Study hypothesis}

The study seeks to test the following hypothesis: There is a statistically significant relationship at $(\alpha \leq 0.05)$ between the use of smartphones and their various apps and tourism marketing in the Kingdom of Saudi Arabia. 


\subsection{Study methodology}

The study used to test its hypothesis and achieve its objectives, the descriptive and analytical approach with secondary data from books, magazines, periodicals, previous studies and the internet. The primary data was collected through a questionnaire designed for the purpose of testing the study hypotheses and achieving its objectives.

\subsection{Study population and sample}

The study community is represented in the residents of Al-Kharj governorate and the tourism organizations in it. The sample members were randomly selected from users of smartphones and their various apps who go on tourist trips, whether internal or external. A questionnaire, which included 250 items, was distributed.

\subsection{Study tool}

A questionnaire was designed for the subject of the study based on [8] was distributed to the individuals of the randomly selected sample from the study population (residents and users of smartphones apps in Al-Kharj), in order to identify the extent of the spread of smartphones and the effect of using their apps in supporting and developing tourism marketing [13-15] operations in the Kingdom. The survey form included three basic axes. Aiming at an ascertaining the validity of the study hypothesis, and each axis includes a set of questions as follows:

The first axis: Includes a set of questions about the demographic characteristics of the sample.

The second axis: It includes a set of questions that explain the widespread use of smartphones and their apps in the tourism field.

The third axis: Includes a set of questions about the effect of using smart phone technology and its apps on tourism marketing in the Kingdom.

\subsection{Tool validityand reliability}

In order to identify the suitability of the questionnaire form for the objectives of the study and test its hypothesis and its ability to measure its variables. The consistency coefficient (Alpha Cronbach) was used, which reached for the scale as a whole (91.321).

Table 1. Study stability coefficient, Alpha Cronbach

\begin{tabular}{|c|l|c|}
\hline No. & \multicolumn{1}{|c|}{ Study axis } & Cronbach's Coefficient Alpha \\
\hline 1 & First axis & 93.412 \\
\hline 2 & Second axis & 89.856 \\
\hline 3 & Third axis & 91.561 \\
\hline Total & & $\mathbf{9 1 . 3 2 1}$ \\
\hline
\end{tabular}




\section{$2 \quad$ Literature Review}

Studies that dealt with the subject of the study the use of smartphones and their apps in tourism marketing in the Al-Kharj Governorate in the Kingdom of Saudi Arabia are almost non-existent. Few studies have dealt with the subject in countries and regions different from the region, place of studies, and in different subjects as well, including these studies: The study [1] dealt with the barriers of implementing TQM in tourism organizations in Al-Kharj, and has reached a group of conclusions, the most important of which are; there are related barriers to communication and its technical tools. In addition, it recommended that attention should be paid to the apps of communication technology in the tourism organizations in the Kingdom. The study [2] also recommended that new marketing methods be used to promote the tourism product in Al-Kharj. The study [3] recommended working to provide electronic channels and apps to distribute and give information about tourism products and tourism organizations in the Kingdom. As for the study [4], it recommended work to improve the quality of services provided in tourism facilities in Al-Kharj through the use and introduction of modern electronic means which ensure an increase and improvement in the quality of these services. The study [5] presented a set of recommendations in order to reach the target customers of tourism organizations in Al-Kharj, the most important of which, is working on using modern means of communication with customers through smartphones and their variant applications. As for the study [6], it recommended the use of electronic apps and means through smartphones in the distribution and delivery of information on tourism products and services in Al-Kharj Governorate. The study [7] presented a set of recommendations related to activating the management of the relationship with customers with modern technological means and communication techniques and working on designing apps for smartphones, which enhance the relationship of the tourism organization with its customers. The study [10] recommended the use of mobile phones to establish everlasting relationships with customers and the use of apps designed for this purpose. The study [8] recommended using of mobile phone apps in the marketing of tourism products in Egypt and recommended the necessity of designing apps for tourism marketing capable of fully interacting with the requirements of the tourist and the tourism organization. The study [9] dealt with the impact of advertising on the mobile phone on the consumer's purchasing behavior. The study recommended the need to pay attention to design advertisements directed to the consumers through the mobile phone in accordance with the nature of the method used. The study [11] recommended the necessity of using mobile apps to reach customers and establish everlasting relationships with them. As for the study [12], it dealt with the possibility of directing consumers' interest in Egypt towards using a mobile phone in purchasing, and it recommended working on designing attractive apps for consumers to make purchases through the use of a mobile phone. 


\section{Practical Side}

\subsection{The demographic characteristics of the sample}

Table 2. The Demographic Characteristics of the Sample

\begin{tabular}{|l|l|c|c|}
\hline \multicolumn{1}{|c}{ Characteristics } & \multicolumn{1}{|c}{ Category } & Repetition & Percentage100\% \\
\hline \multirow{4}{*}{ Gender } & Male & 180 & 72 \\
\cline { 2 - 4 } & Female & 70 & 28 \\
\hline \multirow{5}{*}{ Income } & Less than 5000 & 70 & 28 \\
\cline { 2 - 4 } & $6000-10000$ & 80 & 32 \\
\cline { 2 - 4 } & $11000-15000$ & 60 & 24 \\
\cline { 2 - 4 } & $16000-20000$ & 20 & 8 \\
\cline { 2 - 4 } & More than 21000 & 10 & 4 \\
\hline \multirow{5}{*}{ Occupation } & Less than high school & 60 & 24 \\
\cline { 2 - 4 } & High School & 55 & 22 \\
\cline { 2 - 4 } & Bachelor's degree & 135 & 54 \\
\hline & Student & 30 & 36 \\
\cline { 2 - 4 } & businessman & 100 & 12 \\
\cline { 2 - 4 } & Employee & 30 & \\
\cline { 2 - 4 } & Jobless unemployed & 30 & 12 \\
\hline
\end{tabular}

From the previous table, we notice the following: (72\%) are males, and this indicates that most of those who go on tourist trips are males, and that $(32 \%)$ of the sample were with income between 6000-10000 riyals. This indicates that, this category of middle-income earners (workers -Employees). We also notice that (54\%) of the sample were holders of a bachelor's degree. In addition, it turns out that $(40 \%)$ of the sample are employees and workers, and this indicates that mobile phone users and its apps related to the tourism sector are those who have work and fixed income.

\subsection{The spread of mobile phone use and its apps in tourism marketing.}

Table 3. Sources of Tourism Information in Al-Kharj Governorate

\begin{tabular}{|c|c|c|c|c|}
\hline \multicolumn{2}{|c|}{$\begin{array}{c}\text { Sources for Obtaining Information } \\
\text { About the Tourist Trip }\end{array}$} & \multirow{2}{*}{$\begin{array}{c}\text { Repetition } \\
90 \\
\end{array}$} & \multirow{2}{*}{$\begin{array}{c}\text { Percentage } \\
36 \\
\end{array}$} & \multirow{2}{*}{$\begin{array}{c}\text { Rank } \\
2 \\
\end{array}$} \\
\hline 1 & Travel and Tourism Companies & & & \\
\hline 2 & World Wide Web & 160 & 64 & 1 \\
\hline Total & & 250 & 100 & \\
\hline \multicolumn{5}{|c|}{ The Preferred Method of Accessing The Internet } \\
\hline 1 & Laptop & 68 & 27 & 2 \\
\hline 2 & Smart Phone & 182 & 73 & 1 \\
\hline Total & & 250 & 100 & \\
\hline
\end{tabular}

We note from Table No. (3) That the vast majority of the study sample obtains tourism information through the apps for their phones $(64 \%)$ and it ranked the firstplace. Travel and tourism agencies were ranked in the second place (36\%), and 
(73\%) use telephones to access the Internet and obtain tourist information. Moreover, $(27 \%)$ of the sample used a laptop computer to connect to the Internet and obtain tourist information.

Table 4. The Method Used To Purchase The Tourist Trip

\begin{tabular}{|c|l|c|c|c|}
\hline \multicolumn{1}{|c|}{ The Preferred Way to Book and Purchase A Tourist Trip } & Repetition & Percentage & Rank \\
\hline 1 & Websites & 82 & 32.8 & 2 \\
\hline 2 & Travel and Tourism Companies & 48 & 19.2 & 3 \\
\hline 3 & Tourist Applications in Smartphones & 120 & 48 & 1 \\
\hline Total & $\mathbf{2 5 0}$ & $\mathbf{1 0 0}$ & \\
\hline
\end{tabular}

We notice from Table (4) that (48\%) of the sample use their smartphones and tourism apps to purchase a tourist trip and was ranked the first place. While (32.8) use the internet in the purchasing process for the tourist trip and was ranked in the second place. (19.2\%) of the sample purchases, the tourist trip directly from travel and tourism companies, and it was ranked in the third place.

Table 5. The Uses of Smartphones during the Tourist Trip

\begin{tabular}{|c|l|c|c|c|}
\hline \multicolumn{1}{|c|}{ Smartphone Uses } & Repetition & Percentage & Rank \\
\hline 1 & Multimedia & 34 & 13.6 & 4 \\
\hline 2 & Make Calls & 62 & 24.8 & 1 \\
\hline 3 & Internet Connection & 46 & 18.4 & 3 \\
\hline 4 & Uses Related to Travel and Tourism & 54 & 21.6 & 2 \\
\hline 5 & Games and Entertainment & 23 & 9.2 & 6 \\
\hline 6 & Get News and Information & 31 & 12.4 & 5 \\
\hline
\end{tabular}

From Table No. (5) We notice that $(24.8 \%)$ of the study sample use smartphones, while $(21.6 \%)$ of them use smartphones and their apps in the travel and tourism process, which is a high percentage. It is also clear that $(18.4 \%)$ use smartphones to access the internet, while (13.6\%) use their smartphones to connect to the media. 


\subsection{The effect of using smartphone apps in tourism marketing.}

Table 6. The easiness of using smartphones apps in tourism marketing

\begin{tabular}{|c|l|c|c|c|}
\hline No. & \multicolumn{1}{|c|}{ Paragraph } & Arithmetic mean & Standard derivation & Rank \\
\hline 1 & $\begin{array}{l}\text { The process of purchasing through the } \\
\text { tourism apps via the smart phone saves time } \\
\text { and effort compared to traditional means. }\end{array}$ & 0.896 & 3.725 & 6 \\
\hline 2 & $\begin{array}{l}\text { The ability to control the quality of the } \\
\text { tourism apps that I download to my } \\
\text { smartphone. }\end{array}$ & 4.125 & 0.635 & 3 \\
\hline 3 & $\begin{array}{l}\text { The ability to control the type of tourist } \\
\text { information / advertisements that I receive } \\
\text { via my smartphone. }\end{array}$ & 3.965 & 0.732 & 4 \\
\hline 4 & $\begin{array}{l}\text { Tourist apps via the smartphone are easy to } \\
\text { use. }\end{array}$ & 4.423 & 0.652 & 1 \\
\hline 5 & $\begin{array}{l}\text { Financial transactions via smartphone apps } \\
\text { are done with complete security. }\end{array}$ & 3.951 & 0.640 & 5 \\
\hline 6 & $\begin{array}{l}\text { The possibility of using the tourism apps via } \\
\text { the smartphones without the help nor } \\
\text { guidance of anyone. }\end{array}$ & 4.217 & 0.628 & $\mathbf{0 . 7 1 0}$ \\
\hline Total
\end{tabular}

* (1 - less than 2.8) weak, (2.8 - less than 3.6) medium, (3.6-5) high

It is clear from Table (6) that the majority of the sample agrees that the use of tourism apps is easy, and they do not need help with it. They also agreed that there is a possibility to control the type of tourism apps that they installed on their smartphones in line with their desires, and that there is a possibility to control the quality of the tourist information and advertisements they receive through their smartphones. As they agreed that the financial transactions and payment methods via smartphones are safe, in addition to the effort, time and easiness that tourism apps provide via smartphones. From the above, it is clear that the use of tourism apps in reaching customers and communicating with them is easy and safe.

Table 7. Quality of content for tourism applications

\begin{tabular}{|c|l|c|c|c|}
\hline No. & \multicolumn{1}{|c|}{ paragraph } & $\begin{array}{c}\text { Arithmetic } \\
\text { mean }\end{array}$ & $\begin{array}{c}\text { Standard } \\
\text { derivation }\end{array}$ & Rank \\
\hline 1 & $\begin{array}{l}\text { All the information I get when using the tourist apps is } \\
\text { necessary and reliable. }\end{array}$ & 3.901 & 0.702 & 5 \\
\hline 2 & $\begin{array}{l}\text { Smartphone apps provide many entertainment means during } \\
\text { the tourist trip (games, pictures, music). }\end{array}$ & 4.562 & 0.596 & 1 \\
\hline 3 & $\begin{array}{l}\text { The contents of the tourism apps via the smartphone are } \\
\text { simple and clear. }\end{array}$ & 3.956 & 0.743 & 3 \\
\hline 4 & $\begin{array}{l}\text { The contents of the tourism apps are compatible with the } \\
\text { capabilities of my smartphone. }\end{array}$ & 3.956 & 0.743 & 4 \\
\hline 5 & Words and terminology used in apps are clear & 4.204 & 0.622 & 2 \\
\hline 6 & $\begin{array}{l}\text { Error levels are reduced when using the tourist smartphone } \\
\text { applications. }\end{array}$ & 3.523 & 0.756 & 6 \\
\hline Total & & $\mathbf{3 . 9 6 1}$ & $\mathbf{0 . 7 2 1}$ & 6 \\
\hline
\end{tabular}

* (1 - less than 2.8) weak, (2.8 - less than 3.6) medium, (3.6-5) high 
From Table No. (7) We notice that the majority of the study sample believes that tourism apps provide many entertainment means during the tourist trip (photos games - video - music). They also see that the words and terms used in the apps are clear and their contents are simple and easy to use, and they see that the design of these tourism apps is compatible with the capabilities of their smartphones. Most of the information they obtain through tourism apps is useful and reliable, and that error levels are reduced when they use tourism apps on their smartphones. This indicates to confidence in the content provided by tourism apps in smartphones.

Table 8. The Effect of Using Tourism Apps on the Tourism Trip Purchase Decision

\begin{tabular}{|c|l|c|c|c|}
\hline No. & \multicolumn{1}{|c|}{ Paragraph } & $\begin{array}{c}\text { Arithmetic } \\
\text { mean }\end{array}$ & $\begin{array}{c}\text { Standard } \\
\text { derivation }\end{array}$ & Rank \\
\hline 1 & $\begin{array}{l}\text { Tourist apps via the smartphone help me obtain the necessary } \\
\text { information to make a purchase decision. }\end{array}$ & 3.967 & 0.692 & 3 \\
\hline 2 & $\begin{array}{l}\text { Purchasing the tourist trip (transportation, accommodation, tourism } \\
\text { services) through the tourism apps via the smartphone is one of the } \\
\text { most convenient ways. }\end{array}$ & 4.321 & 0.631 & 1 \\
\hline 3 & $\begin{array}{l}\text { The information and data available in the tourism apps via the } \\
\text { smartphone is a source for your reference when making a purchase } \\
\text { decision. }\end{array}$ & 4.012 & 0.699 & 2 \\
\hline 4 & $\begin{array}{l}\text { Advertising through smartphone apps is one of the most appropriate } \\
\text { marketing methods to attract customers. }\end{array}$ & 3.562 & 0.782 & 4 \\
\hline Total & $\mathbf{3 . 8 1 1}$ & $\mathbf{0 . 7 5 8}$ & \\
\hline
\end{tabular}

* (1 - less than 2.8) weak, (2.8 - less than 3.6) medium, (3.6-5) high

We notice from Table No. (8) The majority of the study sample believes that purchasing a tourist trip using tourism apps is one of the safest ways to purchase. The data and information available through these apps is the source that the sample returns to when making the decision to buy a tourist trip, and you also see that advertisements through tourism apps are one of the most convincing and attracting means for tourists in order to buy a tourist trip. This indicates that the majority of the study sample prefers the tourism apps available on smartphones to obtain information about the tourist trip and complete the purchase process through these applications.

\subsection{Hypothesis testing}

Table 9. Testing the study hypothesis

\begin{tabular}{|c|c|c|c|c|c|}
\hline Mean & Sd. Devotion & t. Critical Value & t. calculated value & Degrees of freedom df & Sig.* \\
\hline 3.904 & 0.703 & 1.564 & 0.395 & 37 & 0.795 \\
\hline
\end{tabular}

* Significant correlation at the level of significance $(\alpha=0.05)$.

We notice from Table No. (9) That the average value of the study axes as a whole was (3.904) with a standard deviation (0.703) and the value of $t$ was (1.564), which means accepting the hypothesis of the study, which states;

There is a statistically significant relationship at $(\alpha \leq 0.05)$ between the use of smartphones and their various apps and tourism marketing in the Kingdom of Saudi 
Arabia. In addition, rejecting the alternative hypothesis, which states: There is no statistically significant relationship at $(\alpha \leq 0.05)$ between the use of smartphones and its various apps and tourism marketing in the Kingdom of Saudi Arabia.

\section{Conclusion}

Through analyzing the questionnaire form and testing the hypothesis of the study, we find that there is a use of the internet in obtaining information through mobile phones and its apps related to tourism marketing. As these apps are used to complete the purchasing of tourism products and services in the Al-Kharj Governorate for ease of use. In addition, these tourism apps are used in the process of promoting tourism products and services. Here, an attention must be paidto provide the advanced technology infrastructure that ensures the continuous provision of services via smartphones and their tourism apps, and to work on training workers in the tourism sector in Al-Kharj Governorate to design and use these apps.As well as the participation of the relevant concerned authorities in the tourism sector in the governorate, the municipality, tourism and antiquities in designing these apps, working to increase awareness of the importance of tourism apps via smartphones in tourism marketing, the delivery of information to tourists, work on coordination and cooperation between the various authorities that supervise the tourism activity in AlKharj Governorate.

\section{$5 \quad$ References}

[1] AL-Hazmi, N \&Alkhateeb, T. (2020). Obstacles to implementing total quality management in Saudi Arabia marketing tourism Services. Management Science Letters. 10(3): 507-514. https://doi.org/10.5267/j.msl.2019.9.030

[2] Al-Hazmia, N. (2020). A study on the dimensions of the quality of tourism services in the Kingdom of Saudi Arabia. Management Science Letters. 10(5): 1115-1120. https://doi.org/10.5267/j.msl.2019.10.030

[3] AL-hazmi, N \& Hassan, Y. (2020). Barriers on marketing tourism services and their impacts on customer awareness. Management Science Letters. 10(11): 2603-2608. https://doi.org/10.5267/j.msl.2020.3.033

[4] Al-Hazmi, N. (2020). The impact of information technology on the design of distribution channels. Uncertain Supply Chain Management. 8(3): 505-512. https://doi.org/10. 5267/j.uscm.2020.4.002

[5] Al-Hazmi, N. (2020). Impact of Total Quality Management on Marketing of Tourism Services: An Applied Study on Hotels Located in Al-Kharj, Saudi Arabia International Journal of Management and Economics Invention. 4(1): 1595-1605https://doi.org/10. 18535/ijmei/v4i1.06

[6] AL-hazmi, N. (2020). The impact of market targeting strategies on tourism services. Management Science Letters. 10(12): 2799-2804.https://doi.org/10.5267/j.msl.2020.4.030

[7] Al-Hazmi, N. (2020). The impact of information technology on the impact of customer relationship management on customer retention in travel and tourism organizations. Management Science Letters. 11(2021): 247-252. https://doi.org/10.5267/j.msl.2020.8.009 
Short Paper-The Use of Mobile Phones and their Apps in Tourism Marketing in The Kingdom...

[8] Ataih, A. (2016). The effect of using smart cell phone technology and its applications. The Scientific Journal of the Faculty of Tourism and Hotels. 13(2016): 122-145.

[9] Aughal, A. (2020). The impact of advertising on mobile phones on consumer behavior. Journal of Management and Economics. 3(2020): 245-255.

[10] Nouraldain, M. (2019). The role of social media marketing in managing the relationship with the customer. Arabic Management Journal. 4(2019): 137-148.

[11] Sawar,Y. (2019). Determine students' preferences for mobile services using shared analysis. Organization and Business Journal. 5(2019): 335-353.

[12] Touraih,A. (2019). A proposed model to support the Egyptian consumer acceptance of mobile marketing. Jordanian Journal of Business Administration. 4(2019): 421-439.

[13] Chitralada Suphachaimongkol, Chavalit Ratanatamskul, Siriwan Silapacharanan, Patcha Utiswannakul. (2019). Development of Mobile Application for Sustainable Creative Tourism Assessment using Confirmatory Factor Analysis Approach. International Journal of Interactive Mobile Technologies. 13(6): 27-40. https://doi.org/10.3991/ijim.v13i06. $\underline{10500}$

[14] Erni Widarti, Dadang Eman, Suyoto Suyoto. (2020). User-centered Design for Mobile Apps Guide Service Heritage Tourism in Indonesia. International Journal of Interactive Mobile Technologies. 14(16): 87-100. https://doi.org/10.3991/ijim.v14i16.11312

[15] Emmanuel Oluwatobi Asani, Mmesoma Zuri Chijioke, Ayoola John Shoyombo, Aderonke Anthonia Kayode, Azubuike Ezenwoke, Foluke Okocha. (2019). LF-ViT: Development of a Virtual Reality Guided Tour Mobile App of Landmark University Teaching and Research Farm. International Journal of Interactive Mobile Technologies. 13(5): 110-123. https://doi.org/10.3991/ijim.v13i05.9119

\section{Author}

Dr. Nabil Mahemmed Al-Hazmi, Associate Professor of Marketing and Head of Marketing Department - College of Business Administration, Prince Sattam bin Abdulaziz University in the Kingdom of Saudi Arabia from 2015 until now, Professor of Tourism Marketing and Head of the Department of Tourism Management at Taiz University in the Republic of Yemen from 2008 to 2015. He published many research papers and studies in the field of tourism marketing in the Kingdom of Saudi Arabia and the Republic of Yemen. He has authored a set of books in the field of Marketing Management and Tourism Marketing. One of the trainers accredited by the International Finance Organization (IFC), a certified trainer at the International Labor Organization, and a member of the Board of Directors of the International Business License (IBDL). Email: hazminabil181220@yandex.com

Article submitted 2020-12-19. Resubmitted 2021-01-27. Final acceptance 2021-01-27. Final version published as submitted by the authors. 